$\begin{array}{ll} & \text { Etnográfica } \\ \text { etnográfica } & \text { Revista do Centro em Rede de Investigação em }\end{array}$

Antropologia

vol. $20(3) \mid 2016$

Vol. 20 (3)

\title{
Chimpanzee behavioural flexibility and the sustainability of human-chimpanzee interactions at Cantanhez National Park, Guinea-Bissau
}

Flexibilidade comportamental dos chimpanzés e a sustentabilidade das interações entre humanos e chimpanzés no Parque Nacional de Cantanhez, Guiné-Bissau

\section{Kimberley J. Hockings}

\section{OpenEdition} Journals

\section{Electronic version}

URL: https://journals.openedition.org/etnografica/4753

DOI: 10.4000 /etnografica. 4753

ISSN: 2182-2891

\section{Publisher}

Centro em Rede de Investigação em Antropologia

\section{Printed version}

Date of publication: 1 October 2016

Number of pages: 659-662

ISSN: 0873-6561

\section{Electronic reference}

Kimberley J. Hockings, "Chimpanzee behavioural flexibility and the sustainability of humanchimpanzee interactions at Cantanhez National Park, Guinea-Bissau", Etnográfica [Online], vol. 20 (3) 2016, Online since 28 November 2016, connection on 11 February 2022. URL: http:// journals.openedition.org/etnografica/4753 ; DOI: https://doi.org/10.4000/etnografica.4753

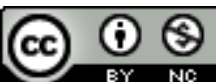

Etnográfica is licensed under a Creative Commons Attribution-NonCommercial 4.0 International License. 


\section{Chimpanzee behavioural flexibility and the sustainability of human-chimpanzee interactions at Cantanhez National Park, Guinea-Bissau}

\section{Kimberley J. Hockings}

This paper incorporates research conducted by Cláudia Sousa and demonstrates the importance of examining chimpanzee behavioural flexibility alongside chimpanzee interactions with local people for the conservation of biodiversity in anthropogenic habitats.

KEYWORDS: human-chimpanzee interactions, sustainability, great ape conservation, chimpanzee behavioural flexibility.

Flexibilidade comportamental dos chimpanzés e a sustentabilidade das interações entre humanos e chimpanzés no Parque Nacional de Cantanhez, Guiné-Bissau - Esta comunicação incorpora investigação conduzida por Cláudia Sousa e demonstra a importância de examinar a flexibilidade comportamental dos chimpanzés e a interação dos chimpanzés com as populações locais para a conservação da biodiversidade em habitats antropogénicos.

PALAVRAS-CHAVE: interação entre humanos e chimpanzés, sustentabilidade, conservação de grandes símios, flexibilidade comportamental dos chimpanzés.

HOCKINGS, Kimberley J. (hock@fcsh.unl.pt) - CRIA; Faculdade de Ciências Sociais e Humanas, Universidade Nova de Lisboa (FCSH/Nova), Portugal.

GROWING HUMAN POPULATIONS ARE ALTERING NATURAL HABITATS across the globe at unprecedented speeds. We are in a new epoch, the Anthropocene, and research into our closest living relatives, the great apes, must keep pace with the rate that our species is changing ape habitat, whether these are islands of protected areas or mosaics of forest patches and farms (Hockings et al. 2015). No long-term great ape research site, even those in protected areas, is wholly free of human influence. However, scientists have only recently appreciated the degree to which great apes can survive in disturbed and degraded ecosystems. Research on great apes across the anthropogenic continuum offers new opportunities to develop understanding of behavioural flexibility (including utilisation of both wild and cultivated food resources) in 
the face of unprecedentedly rapid environmental changes, and allows us to examine the potential for sustainable coexistence to ensure that our great ape kin survive the Anthropocene.

Great apes are charismatic mega-fauna for conservation and important for ecosystem health. However, their slow life histories, large body masses and large home ranges all contribute to the fact that all species and sub-species are listed as endangered or critically endangered by the IUCN, mostly due to habitat destruction and poaching. Great apes - unless hunted or persecuted - have the behavioural flexibility needed to exploit human-modified environments (Hockings et al. 2015). Despite a huge scientific literature on great ape behaviour, ecology and conservation, we are only starting to compile important empirical data on how individuals adjust their behaviour to anthropogenic habitats.

The aim of this paper is to provide an overview of human-chimpanzee interactions at Caiquene-Cadique in Cantanhez National Park (CNP) in Guinea-Bissau. We will briefly examine the diet (including wild and cultivated food) of the residing chimpanzee community, which is one of the most effective ways to understand a community's ability to cope with changing conditions, and discuss how shared resource use might impact the sustainability of interactions with local people.

Cantanhez was declared a National Park in 2008 and these heavily fragmented coastal forests have been identified as one of seven priority areas in West Africa for urgent chimpanzee conservation (Kormos et al. 2003). CNP is $1057 \mathrm{~km}^{2}$ and contains approximately 110 villages and 22,500 people. CNP is a mosaic of settlements, agricultural fields, subhumid forest, secondary forest, mangrove and savannah. Guinea-Bissau is the world's fifth largest cashew exporter (cashew makes up 90\% of the country's exports). There are at least seven species of nonhuman primates at CNP, including the endangered western chimpanzee (Pan troglodytes verus) and red colobus monkey (Procolobus badius temminckii).

Central CNP has several chimpanzee communities (Hockings and Sousa 2013). The Caiquene-Cadique chimpanzees' home-range area is estimated at $8 \mathrm{~km}^{2}$ with a minimum of 40 individuals. Caiquene and Cadique are both small villages and most inhabitants are of Nalú ethnicity. Their tolerance towards chimpanzees is related to a belief that they are ancestors who should have access to resources in their ancestral land (Sousa et al. 2014).

Despite feeding on over 57 wild foods, chimpanzees at Caiquene-Cadique modify their dietary repertoire to include at least nine human crops (Bessa, Sousa and Hockings 2015); mango and orange fruits, as well as cashew pseudofruits are consumed most frequently. Cashew consumption by chimpanzees provides an interesting example for why we should not assume that crop feeding by wildlife is always destructive (Hockings and Sousa 2012). The 
chimpanzees never consume the economically valuable cashew nut, which is surrounded by a double shell containing anarcadic acid that is a potent skin irritant. Instead chimpanzees consume the cashew pseudofruit, placing several fruits in the mouth to make a species-typical wadge. Local farmers report that after eating cashew pseudofruits, chimpanzees leave the nuts in manageable piles thereby making nut collection easier for the farmer. The cashew pseudofruit is fragile and ferments quickly, making it unsuitable for transport and retail. It should however be noted that cashew farming is quite destructive and is responsible for much deforestation and fragmentation at CNP and elsewhere in Guinea-Bissau. The consumption of other crops at CNP are deemed problematic by local people, especially if economically valuable, and wildlife crop feeding can sometimes trigger local people to engage in crop protection practises that might negatively impact the chimpanzees.

In addition to growing crops, local people use a diverse range of wild plants for different reasons, ranging from medicine to subsistence (Frazão-Moreira 2009). However, most resources are used and sold locally. Humans and chimpanzees share a number of key wild resources, including oil-palm (Elaeis guineensis), Saba senegalensis, and Parinari excelsa, which are important to both. The sustainability of resource use by local people and its impact on chimpanzees will depend on a multitude of factors, including its availability within the habitat, the economic value of the resource, and the availability of alternative foods and medicines and so on. These will likely vary across time and space.

From a conservation perspective, strategies to reduce negative interactions between humans and apes should take into account the complex adaptive responses of large-brained species, because solutions often are not straightforward. Effective crop-foraging deterrents must address dynamic feeding changes in apes (Hockings and McLennan 2012). However, "problematic" ape behaviour is only one aspect of "conflict", with human social drivers (such as cultural norms and expectations, social tensions, fear and lack of knowledge) often increasing the intensity of conflict generated. Conservation conflicts are fundamentally driven by humans, who have different goals, agendas, and levels of empowerment (Hill 2015). Hence, cross-disciplinary research is required to gain a real understanding of human and wildlife perspectives of interactions. The survival of large, diverse populations of great apes requires finding ways for humans and apes to coexist both inside and outside protected areas. 


\section{REFERENCES}

BESSA, Joana, Cláudia SOUSA, and Kimberley Jane HOCKINGS, 2015, "Feeding ecology of chimpanzees (Pan troglodytes verus) inhabiting a forest-mangrove-savanna-agricultural matrix at Caiquene-Cadique, Cantanhez National Park, Guinea-Bissau", American Journal of Primatology, 77: 651-665.

FrazÃO-MOReirA, Amélia, 2009, Plantas e "Pecadores": Percepções da Natureza em África, Lisboa, Livros Horizonte.

HILL, Catherine, 2015, "Perspectives of 'conflict' at the wildlife-agriculture boundary: 10 years on”, Human Dimensions of Wildlife, 20: 1-6.

HOCKINGS, Kimberley J., and Cláudia SOUSA, 2012, "Differential utilization of cashew - a low-conflict crop - by sympatric humans and chimpanzees”, Oryx, 46: 375-381.

HOCKINGS, Kimberley J., and Cláudia SOUSA, 2013, "Human-chimpanzee sympatry and interactions in Cantanhez National Park, Guinea-Bissau: current research and future directions", Primate Conservation, 26: 57-65.

HOCKINGS, Kimberley J., and Matthew R. McLENNAN, 2012, "From forest to farm: systematic review of cultivar feeding by chimpanzees: management implications for wildlife in anthropogenic landscapes", PlosOne, 7: e33391, DOI: 10.1371/journal.pone.0033391.

HOCKINGS, K. J., et al., 2015, "Apes in the Anthropocene: flexibility and survival", Trends in Ecology and Evolution, 30: 215-222.

KORMOS, Rebecca, et al., 2003, West African Chimpanzees: Status Survey and Conservation Action Plan. Cambridge, IUCN/SSC Primate Specialist Group.

SOUSA, Joana, et al., 2014, "Local knowledge and perceptions of chimpanzees in Cantanhez National Park, Guinea-Bissau”, American Journal of Primatology, 76: 122-134. 